\title{
Microwave-assisted synthesis and characterization of some optically active poly(ester-imide) thermoplastic elastomers
}

\author{
Saeed Zahmatkesh, ${ }^{1 *}$ Abdol Reza Hajipour ${ }^{2}$ \\ ${ }^{1 *}$ Department of Science, Payame noor University (PNU), Tehran, Iran; fax: \\ 00987324225700; e-mail: zahmatkesh1355@yahoo.com \\ ${ }^{2}$ Department of Pharmacology, University of Wisconsin, Medical School, 1300 \\ University Avenue, Madison, 53706-1532, WI, USA
}

(Received: 23 May, 2008; published: 12 June, 2009)

\begin{abstract}
Pyromellitic dianhydride (1) was reacted with L-leucine (2) to result in $\left[N, N^{\prime}\right.$-(pyromellitoyl)-bis-L-leucine diacid] (3). This compound (3) was converted to $N, N^{\prime}$-(pyromellitoyl)-bis-L-leucine diacid chloride (4) by reaction with thionyl chloride. The microwave-assisted polycondensation of this diacid chloride (4) with polyethyleneglycol-diol (PEG-200) and/or three synthetic bisphenols furnish a series of new PEIs and Co-PEIs in a laboratory microwave oven (Milestone). The resulting polymers and copolymers have inherent viscosities in the range of 0.31 $0.53 \mathrm{dl} \mathrm{g}^{-1}$. These polymers are optically active, thermally stable and soluble in polar aprotic solvents such as DMF, DMSO, NMP, DMAc and sulfuric acid. All of the above polymers were fully characterized by IR spectroscopy, ${ }^{1} H$ NMR spectroscopy, elemental analyses, specific rotation and thermal analyses. Some structural characterizations and physical properties of these optically active PEIs and Co-PEls are reported.
\end{abstract}

\section{Introduction}

Due to the increasing demand for high-performance polymers as a replacement for ceramics or metals in the microelectronic, aerospace and automotive industries, thermally stable polymers have received much interest over the past decade. Polyimides and their copolymers are certainly one of the most useful classes of highperformance polymers, which have found many applications in industries [1, 2]. Aromatic polyimides are an important class of heterocyclic polymers with remarkable heat resistance and superior mechanical and electrical properties, and also durability [3-5]. Poor thermoplastic fluidity and solubility are the major problems in wide application of polyimides. This makes it impossible for most polyimides to be directly processed in their imidized forms; thus, their applications have been restricted in some fields. Processable engineering plastics possessing moderately high softening temperatures and/or solubility in some organic solvents are required for practical use. Therefore, various efforts have been focused on the preparation of soluble and/or thermoplastic polyimides, while still maintaining the excellent thermal and mechanical properties. Typical approaches employed to improve the processability of these polyimides include the incorporation of flexible links [6], bulky pendant or cardo groups [7], kinked or unsymmetrical structures [8], and spiro-skeletons [9] into the polymer chain. These modifications lower the melting temperature and lead to soluble and amorphous polymers. In general, amorphous polymers have a lower softening temperature $\left(T_{g}\right)$ and improved solubility with respect to their crystalline 
analogues. Some of the block copolymers composed of polyethers and polyamides have already been commercialized as thermoplastic elastomers [10]. A number of synthetic routes for polyether-polyimide block copolymers have been known [11]. Ether linkages inserted in the main chains provide them with significantly lower energy of internal rotation.

The synthesis and application of optically active polymers are the newly considered topics which have been paid more attention recently [12]. Most of the natural polymers are optically active and have special chemical activities, such as catalytic properties that exist in genes, proteins and enzymes. Some other applications are construction of chiral media for asymmetric synthesis, chiral stationary phases for resolution of enantiomers in chromatographic techniques [13-17], chiral liquid crystals in ferroelectrics and nonlinear optical devices [18-21]. These synthetic polymers based on optically pure aminoacids can induce crystallinity with their ability to form higher ordered structures that exhibit enhanced solubility characteristics [22]. These properties have caused them to be good candidate for drug delivery systems, biomimetic systems, biodegradable macromolecules, biomaterials, and also as chiral purification media [23]. So, more considerations to improve different synthetic procedures of optically active polymers exist. Recently, we have synthesized optically active polymers by different methods [24-26].

Organic reactions assisted by microwave irradiation have gained special attention. The reactions are very fast and are completed within short times [27-32]. Recently we have used microwave irradiation to synthesize organic compounds as well as macromolecules [33-36]. In this research, we report the synthesis and characterization of some PEls and Co-PEIs by microwave-assisted polycondensation method in a laboratory microwave oven. These polymers showed good optical activity $(+19.9$ to +40.7$)$ and also because of the presence of benzophenone moiety, the polymers containing it, can potentially be photolabile [37]. The photolabile polymers are potentially able to be used as affinity columns for protein purification [37]. The outstanding characteristics of these polymers include thermal stability, good solubility, improved optical activity and being photolabile.

Here, we have also investigated the effect of catalyst, irradiation power and time of irradiation on optical activity and viscosity of polymers.

\section{Results and discussion}

We synthesized the diimide-diacid [N,N'-pyromelliticdiimido-di-L-leucine(3)] by the condensation reaction of dianhydride (1) with L-leucine (2) in 1:2 molar ratio in refluxing acetic acid/pyridine (3:2). Washing the residue with cold water yields a gummy layer which breaks by adding concentrated $\mathrm{HCl}$ into a white solid (Scheme 1).

IR spectrum of this diacid shows the characteristic absorptions at around 3400-2250 $\mathrm{cm}^{-1}$, peculiar to carboxylic acid groups, two peaks at around 1770 and $1700 \mathrm{~cm}^{-1}$, peculiar to carbonyl stretching of imide and acid moieties, and exhibits strong absorptions at 1388 and $725 \mathrm{~cm}^{-1}$, that indicates the presence of the cyclic imide group. ${ }^{1} \mathrm{H}$ NMR of diimide-diacid 1 is presented in Figure 1 . The corresponding peaks includpng acidic groups at around $13.4 \mathrm{ppm}$ have been detected by ${ }^{1} \mathrm{H}$ NMR. Mass spectra showed the appropriate molecular ion peaks and/or fragments. The chlorination was completed after $2 \mathrm{~h}$, when the mixture was completely dissolved in refluxing thionyl chloride. 


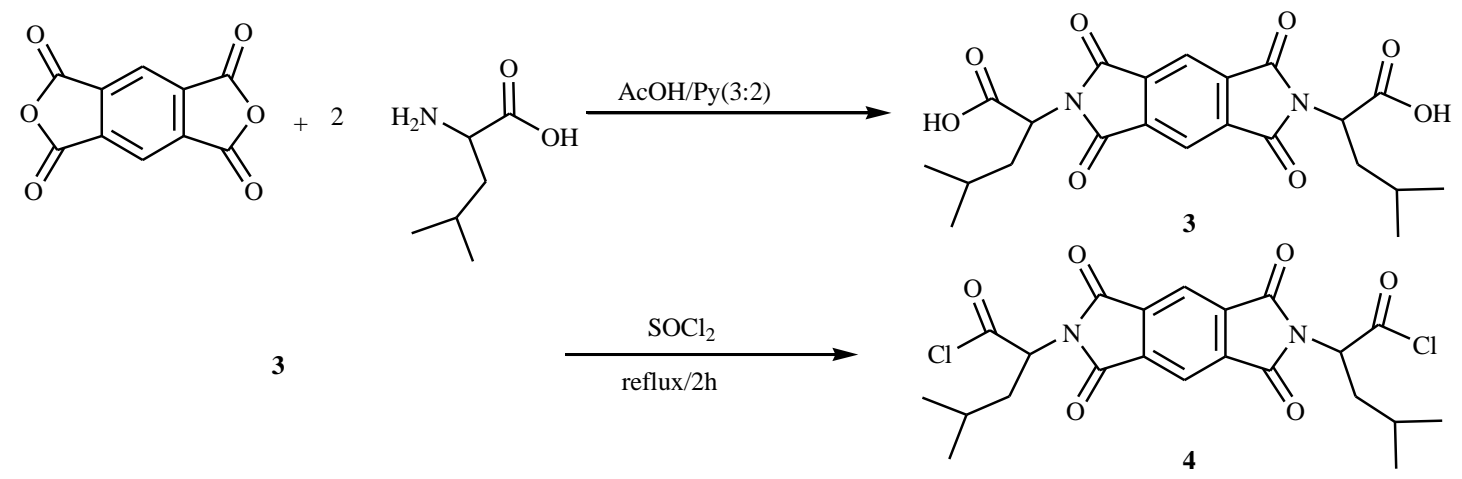

Scheme 1. Preparation of diacid $\mathbf{3}$ and diacid chloride 4.
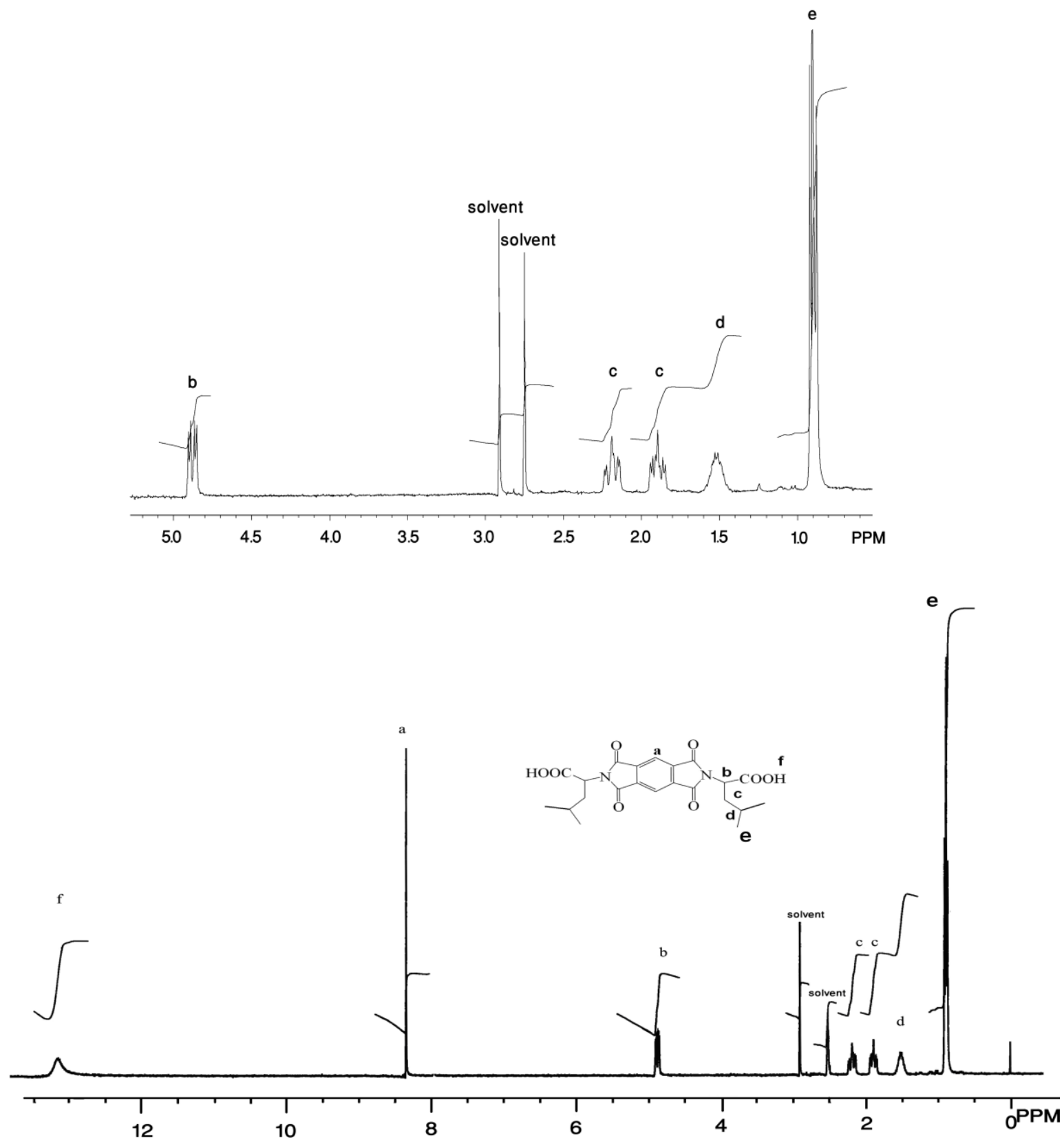

Fig. 1. ${ }^{1} \mathrm{H}$ NMR spectrum of diacid (3). 
Figure 2 shows IR spectrum of diacid chloride (4). DMF plays a catalytic role in this reaction. The characteristic peak at around $1850 \mathrm{~cm}^{-1}$ is due to the acyl chloride carbonyl group. The acyl chloride will decompose on heating at $128-130{ }^{\circ} \mathrm{C}$, so its mass spectrum did not show the molecular ion peak by El technique, but some fragments have been seen.

This monomer is the source of chirality in the corresponding polymers. Bisphenol 7 was prepared as mentioned in the experimental part (Fig 3).

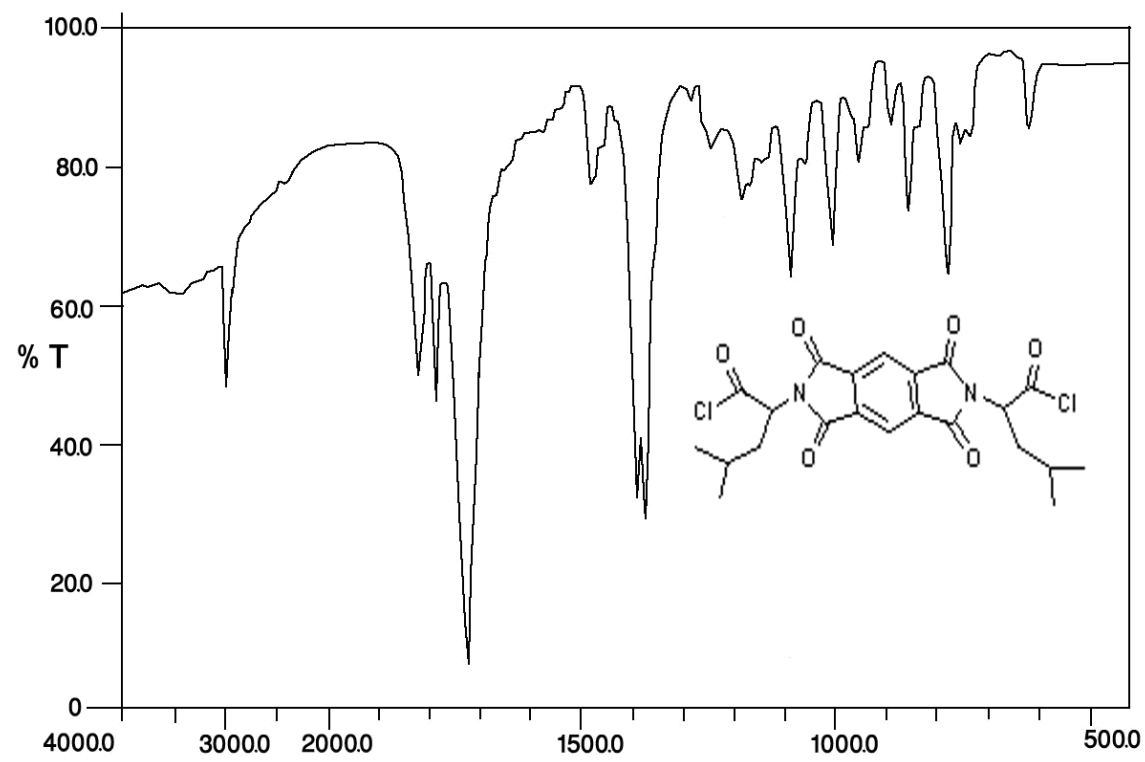

Fig. 2. IR spectrum of diacid chloride (4).

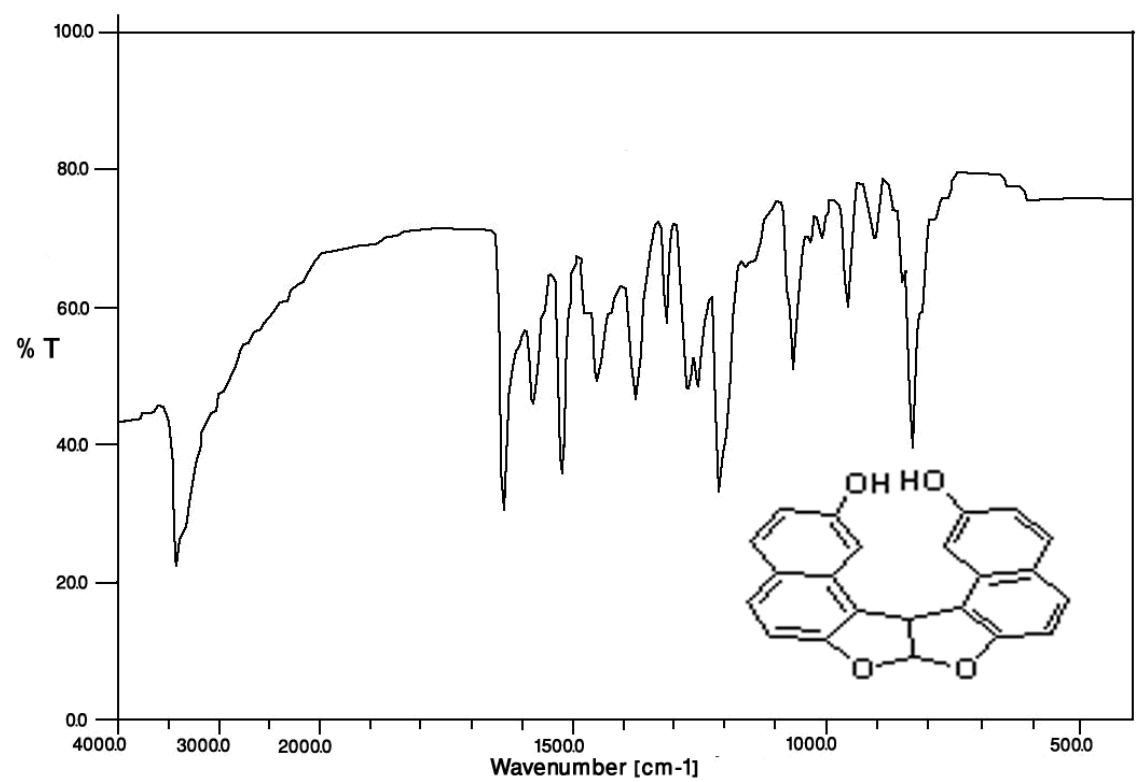

Fig. 3. IR spectrum of bisphenol 7.

The dark purple solids turned to white needle crystals after recrystallization from EtOH (Scheme 2). In the preparation of bisphenols $\mathbf{5}$ and $\mathbf{6}$ after stirring at r.t. for 2 hours the corresponding amic acids formed which turned to the corresponding imide 
rings after 10 hours reflux. These bisphenols were yellow powders, which showed high melting points, low solubility, and very low vapour pressure so that we could not run their mass spectra by El technique.<smiles>Cc1ccc(O)cc1</smiles><smiles>C[14C](C)c1ccc(N2C(=O)c3ccc(C(=O)c4ccc5c(c4)C(=O)N(c4ccc(O)cc4)C5=O)cc3C2=O)cc1</smiles><smiles>O=CCOC(=O)CCCCCCO</smiles><smiles>Oc1ccc2ccc3c(c2c1)C1c2c(ccc4ccc(O)cc24)OC1O3</smiles>

Scheme 2: Preparation of diols.

In IR spectra, the characteristic peaks at around $3400 \mathrm{~cm}^{-1}$ and in ${ }^{1} \mathrm{H}$ NMR the peaks at around $9.7 \mathrm{ppm}$ show the phenolic $(\mathrm{OH})$ groups. These bisphenols are good candidates to improve the thermal stability of the corresponding polymers. Figure 4 shows ${ }^{1} \mathrm{H}$ NMR spectrum of bisphenol 6.

The microwave-assisted polycondensation method was used to prepare PEls (1-3) and Co-PEls (4-6) (Schemes 3 and 4).

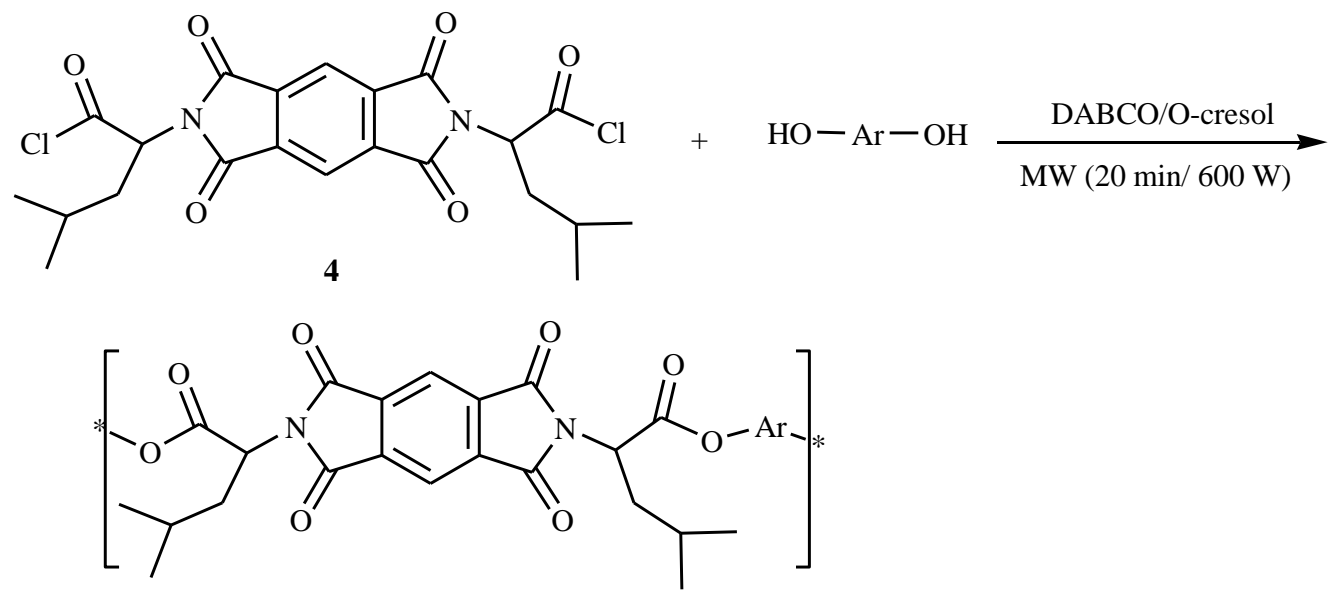

$\mathbf{P E I}_{1}, \mathrm{PEI}_{2}, \mathrm{PEI}_{3}$<smiles>Cc1ccc(N2C(=O)C3C(=O)N(c4ccc(C)cc4)C(=O)C3C2=O)cc1</smiles><smiles>Cc1ccc(N2C(=O)C3C=CC(C3=O)C(=O)N(c3ccc(C)cc3)C2=O)cc1</smiles>

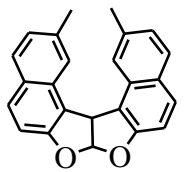

Scheme 3. Preparation of polymers $\left(\mathrm{PEI}_{1-3}\right)$. 


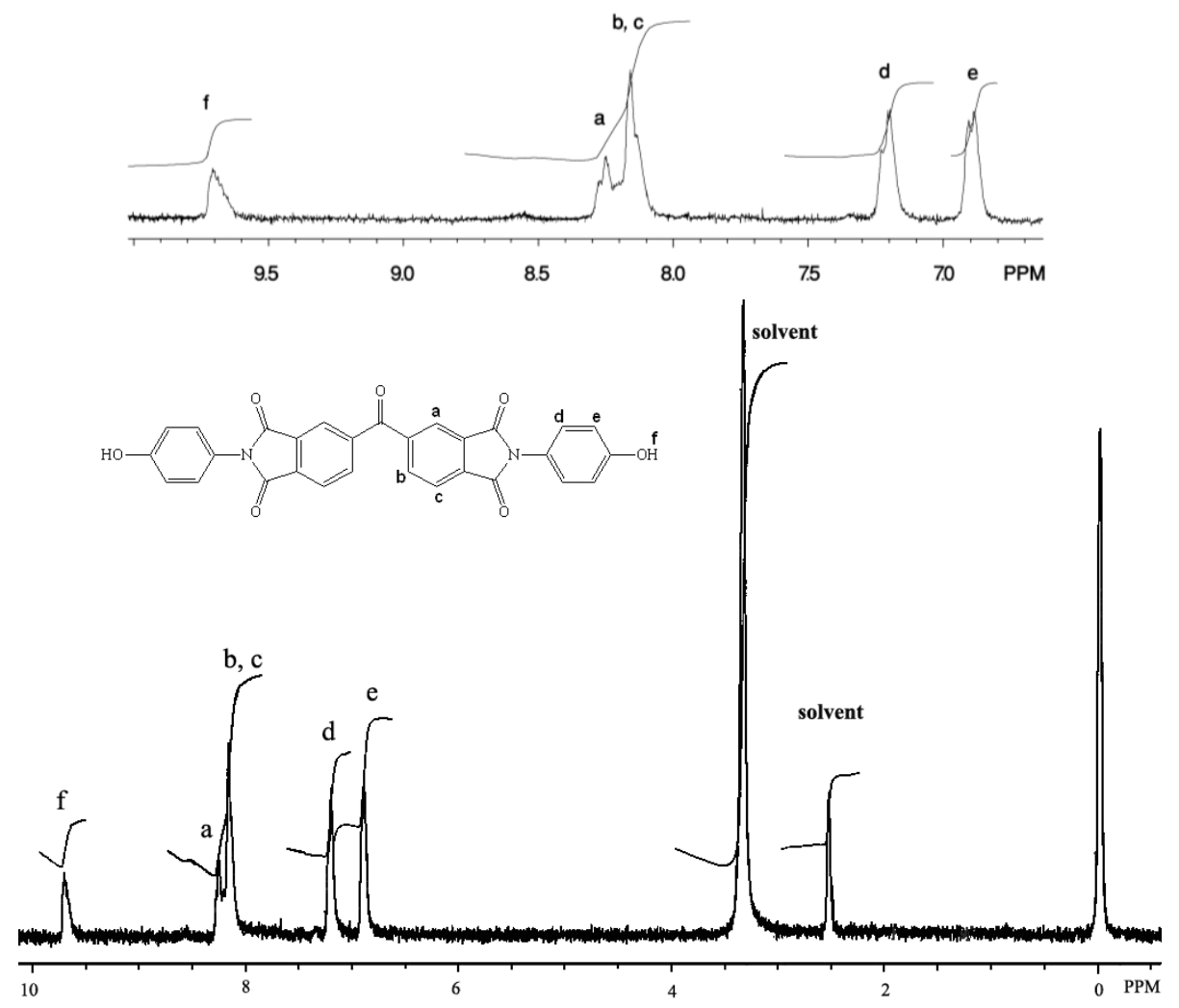

Fig. 4. ${ }^{1} \mathrm{H}$ NMR spectrum of bisphenol 6.

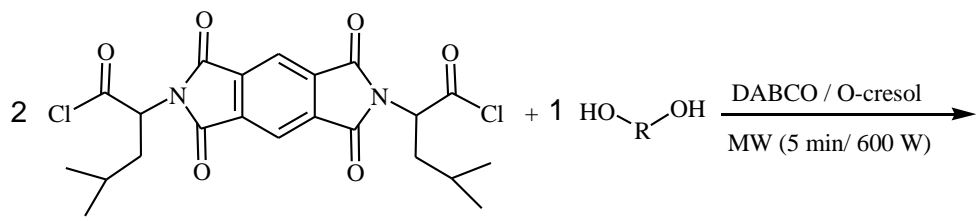

R: $\mathrm{CH}_{2} \mathrm{CH}_{2} \mathrm{OCH}_{2} \mathrm{CH}_{2} \mathrm{OCH}_{2} \mathrm{CH}_{2} \mathrm{OCH}_{2} \mathrm{CH}_{2}$

1<smiles>CC(C)CC(C(=O)Cl)n1c(=O)c2cc3c(=O)n(C(CC(C)C)C(=O)OCCOCCOCCOC(=O)C(CC(C)C)n4c(=O)c5cc6c(=O)n(C(CC(C)C)C(=O)Cl)c(=O)c6cc5c4=O)c(=O)c3cc2c1=O</smiles>

1 A +1 HOArOH $\underset{\mathrm{MW}(20 \mathrm{~min} / 600 \mathrm{~W})}{\stackrel{\mathrm{DABCO} / \mathrm{O}-\text { cresol }}{\longrightarrow}}$<smiles>[H][Y9]([H])(C)OC(=O)C(CC(C)C)n1c(=O)c2cc3c(=O)n(C(CC(C)C)C(=O)O[Al]OC(=O)C(CC(C)C)n4c(=O)c5cc6c(=O)n(C(CC(C)C)C(=O)OC(C)C)c(=O)c6cc5c4=O)c(=O)c3cc2c1=O</smiles>

Co-PEI 4 , Co-PEI $5, \mathrm{Co}_{5}-\mathrm{PEI}_{6}$

Scheme 4: Preparation of copolymers (Co-PEI $4-6$ ).

6 
The resulting homogenous glassy compound films were isolated by adding methanol/ $\mathrm{H}_{2} \mathrm{O}(80: 20)$ and triturating, followed by filtration. It was washed several times with methanol and vacuum dried. To optimize the polymerization conditions, we did six experiments on $\mathbf{P E I}_{1}$. The optimum condition is as follows: power=600 W; time=20 min with interval times of $10 \mathrm{sec} / \mathrm{min}$ of running. It is found that at higher power, the lower viscosity and lower specific rotation is obtained; which can be attributed to polymer degradation.

At lower power, the higher specific rotation but lower viscosity is obtained; the results are shown in Table 1.

Tab. 1. Optimization of microwave-assisted polycondensation on $\mathbf{P E I}_{1}$.

\begin{tabular}{ccccc}
\hline Power & Time $(\mathrm{min})$ & $\begin{array}{c}\text { Interval }(10 \\
\text { sec } / \text { min })\end{array}$ & ク́inh $\left._{\text {(dl g }}{ }^{-1}\right)$ & {$[\alpha]_{D}^{25}$} \\
\hline 800 & 10 & - & 0.21 & +16.7 \\
800 & 10 & + & 0.30 & +21.4 \\
600 & 10 & + & 0.33 & +26.3 \\
600 & 20 & + & 0.37 & +30.3 \\
400 & 20 & + & 0.28 & +32.2 \\
300 & 20 & + & 0.19 & +34.5 \\
\hline
\end{tabular}

All the polymers were obtained in quantitative yields with moderate inherent viscosities (0.31-0.53 dl g-1) and optical rotation. The formation of PEls and Co-PEls was confirmed by IR and ${ }^{1} \mathrm{H}$ NMR spectroscopy and elemental analysis. As an example, the IR of Co- $\mathrm{PEI}_{6}$ showed the $\mathrm{C}=\mathrm{O}$ asymmetric stretching of imide group at $1780 \mathrm{~cm}^{-1}$, the $\mathrm{C}=\mathrm{O}$ symmetric stretching of imide and ester groups at $1725 \mathrm{~cm}^{-1}$, C$\mathrm{N}$ stretching at $1380 \mathrm{~cm}^{-1}, \mathrm{C}-\mathrm{O}-\mathrm{C}$ stretching at $1280-1030 \mathrm{~cm}^{-1}$. All of these PEls and Co-PEls exhibited strong absorption at 1380 and $720 \mathrm{~cm}^{-1}$, which shows the presence of the heterocyclic imide groups. The ${ }^{1} \mathrm{H}$ NMR spectra of $\mathrm{PEI}_{1}$ and $\mathbf{C o}-\mathrm{PEI}_{6}$ showed peaks that confirm their chemical structures (Fig. 5). The elemental analyses results are also in good agreement with calculated/expected percentages of carbon, hydrogen and nitrogen contents in the polymer-repeating units. The colours of these polymers range from white-grey to grey. Transparent, flexile and tough films could be obtained from these polymers by casting from solution of polymers in DMF, which shows good mechanical strength of the films and consequently high molecular weight. One of the major objectives of this work is to study the solubility and the flexibility of these polymers by incorporating the soft segment in the polymer backbone. Their solubility was tested qualitatively in various solvents and the results are summarized in Table 2.

Having soft segments in the polymer backbone will increase the solubility, so here Co-PEls showed very good solubility; all of them are soluble in polar aprotic solvents such as DMF, DMAc, DMSO, NMP and also $\mathrm{H}_{2} \mathrm{SO}_{4}$ at room temperature. They are insoluble in solvents, such as chloroform, methylene chloride, methanol, ethanol and water. These polymers showed improved optical activity $(+30.3$ to +51.5$)$ and also because of the presence of benzophenone moiety, the polymers containing it, can potentially be photolabile. When compared to PEIs, Co-PEls showed higher viscosities and better solubility. 

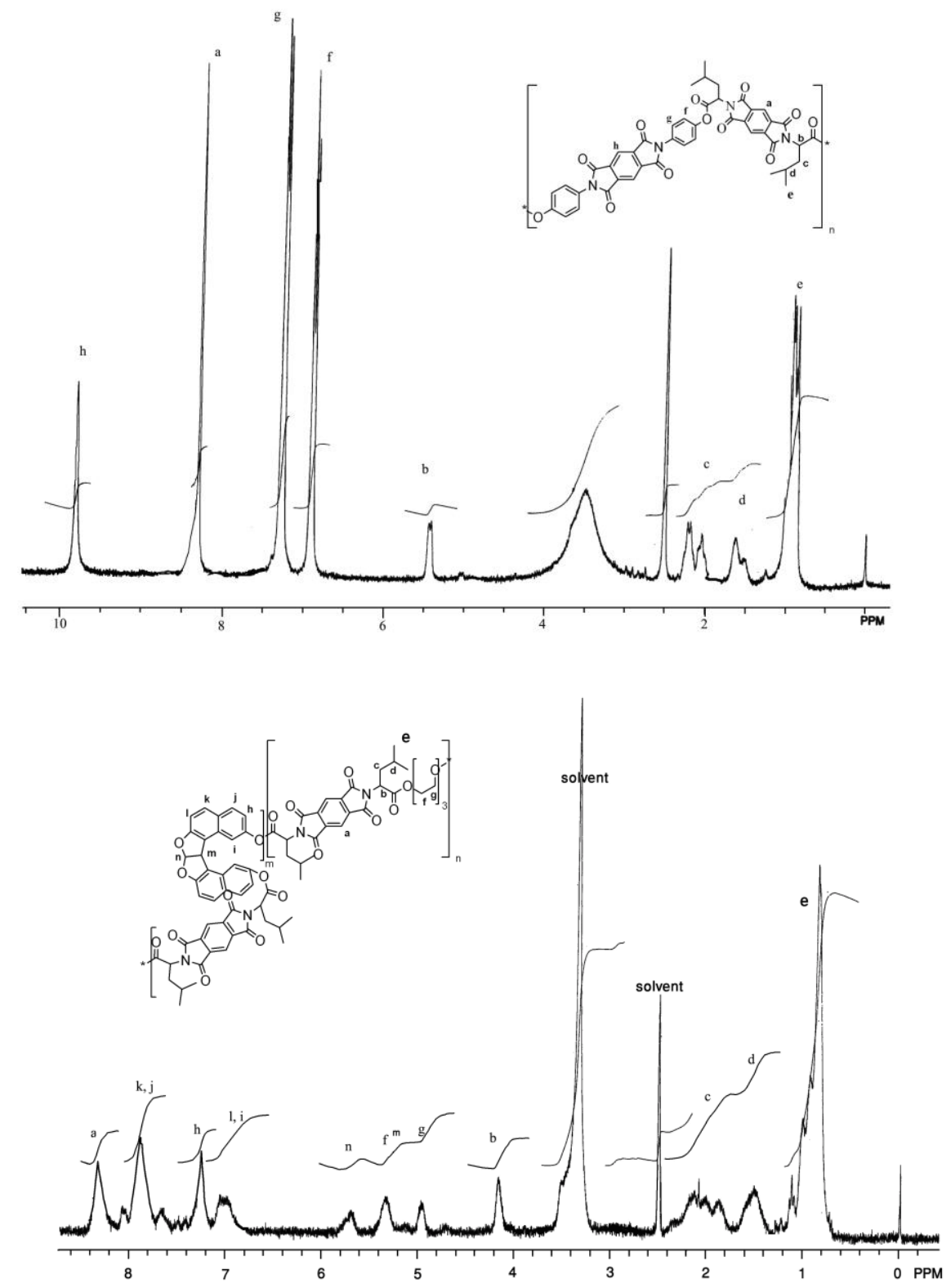

Fig. 5. ${ }^{1} \mathrm{H}$ NMR spectra of $\mathrm{PEI}_{1}$ and Co-PEI .

Tab. 2: Solubility of PEls and Co-PEls ${ }^{a}$.

\begin{tabular}{ccccccc}
\hline Solvents & PEI $_{1}$ & PEI $_{2}$ & PEI $_{3}$ & Co-PEI & Co-PEI & Co-PEI \\
\hline NMP & + & + & ++ & ++ & ++ & ++ \\
DMSO & + & + & ++ & ++ & ++ & ++ \\
DMAc & + & + & ++ & ++ & ++ & ++ \\
$\mathrm{DMF}$ & + & + & ++ & ++ & ++ & ++ \\
$\mathrm{H}_{2} \mathrm{SO}_{4}$ & + & + & ++ & ++ & ++ & ++ \\
$\mathrm{CH}_{2} \mathrm{Cl}_{2}$ & - & - & - & - & - & - \\
$\mathrm{CHCl}_{3}$ & - & - & - & - & - & - \\
$\mathrm{EtOH}$ & - & - & - & - & - & - \\
$\mathrm{MeOH}$ & - & - & - & - & - & - \\
$\mathrm{H}_{2} \mathrm{O}$ & - & - & - & - & - & - \\
\hline${ }^{a}$ Concentration: $5 \mathrm{mg} \mathrm{ml}^{-1}:++$, soluble at room temperature; +, soluble upon heating; -, insoluble.
\end{tabular}


The thermal properties of these polymers were evaluated by means of TGA/DTG (under air atmosphere) and DSC (under nitrogen atmosphere). These polymers show similar decomposition behaviour. They showed two different decomposition maxima. Table 3 summarize the thermal properties of these polymers.

Tab. 3. Thermal behavior of PEls and Co-PEls.

\begin{tabular}{|c|c|c|c|c|}
\hline Polymer & $\begin{array}{c}\text { Decomposition } \\
\text { temperature } \\
\left({ }^{\circ} \mathrm{C}\right) \mathrm{T}_{5 \%}{ }^{\mathrm{a}}\end{array}$ & $\begin{array}{c}\text { Decomposition } \\
\text { temperature } \\
\left({ }^{\circ} \mathrm{C}\right) \mathrm{T}_{10 \%}{ }^{\mathrm{b}}\end{array}$ & $\begin{array}{c}\text { Char yield } \\
(\%)^{c}\end{array}$ & $\mathrm{~T}_{\mathrm{g}}\left({ }^{\circ} \mathrm{C}\right)^{\mathrm{d}}$ \\
\hline $\mathrm{PEI}_{1}$ & 390 & 410 & 1.2 & No $\mathrm{Tg}$ \\
\hline $\mathrm{PEI}_{2}$ & 335 & 350 & 1.4 & No Tg \\
\hline $\mathrm{PEI}_{3}$ & 390 & 400 & 0.1 & No Tg \\
\hline $\mathrm{Co}-\mathrm{PEI}_{4}$ & 400 & 420 & 0.5 & 143 \\
\hline Co-PEI 5 & 365 & 395 & 0.2 & 130 \\
\hline Co-PEI 6 & 370 & 390 & 0.4 & 140 \\
\hline
\end{tabular}

${ }^{\text {a }}$ Temperature at which $5 \%$ weight loss was recorded by TGA at a heating rate of $10{ }^{\circ} \mathrm{C} / \mathrm{min}$ under air atmosphere. ${ }^{b}$ Temperature at which $10 \%$ weight loss was recorded by TGA at a heating rate of $10^{\circ} \mathrm{C} /$ min under air atmosphere. ${ }^{\mathrm{C}}$ Percentage weight of material left after TGA analysis at maximum temperature $600^{\circ} \mathrm{C}$ under air atmosphere. ${ }^{d}$ Glass transition temperature.

These polymers exhibited good resistance to thermal decomposition. (5\% weight loss: $335^{\circ} \mathrm{C}$ to $400{ }^{\circ} \mathrm{C}$ and $10 \%$ weight loss: $350^{\circ} \mathrm{C}$ to $420{ }^{\circ} \mathrm{C}$ ). $\mathrm{T}_{\mathrm{g}}$ values of Co-PEls are from $130{ }^{\circ} \mathrm{C}$ to $143^{\circ} \mathrm{C}$. TGA/DTG thermogram of $\mathrm{PEI}_{1}$ is represented in Figure 6 .

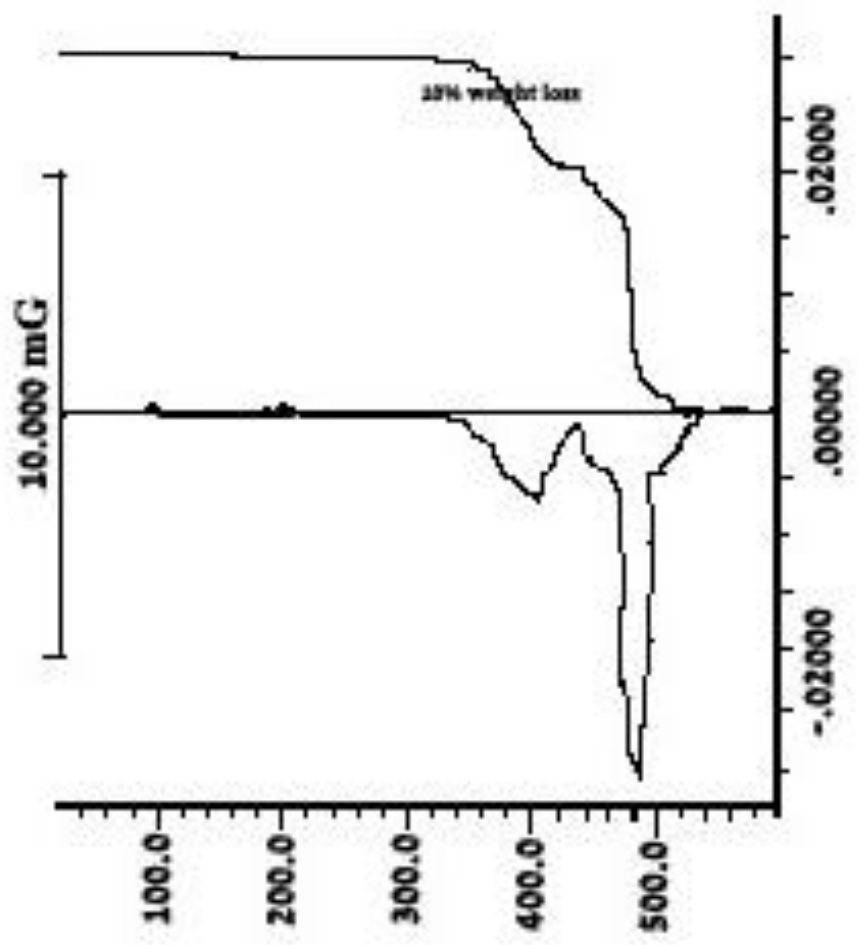

Fig. 6. TGA/DTG thermogram of $\mathrm{PEI}_{1}$ under air atmosphere.

TGA/DTG and DSC thermograms of Co-PEI ${ }_{6}$ are represented in Figure 7. DSC thermogram of $\mathbf{P E I}_{1}$ did not show a clear $\mathrm{T}_{\mathrm{g}}$, but expectedly that of Co-PEI $\mathbf{I}_{6}$, since of 
soft segment in the polymer backbone which cause an increase in phase separation along with decreasing thermooxidative stability have shown a $T_{g}$ value of about 140 ${ }^{\circ} \mathrm{C}$.

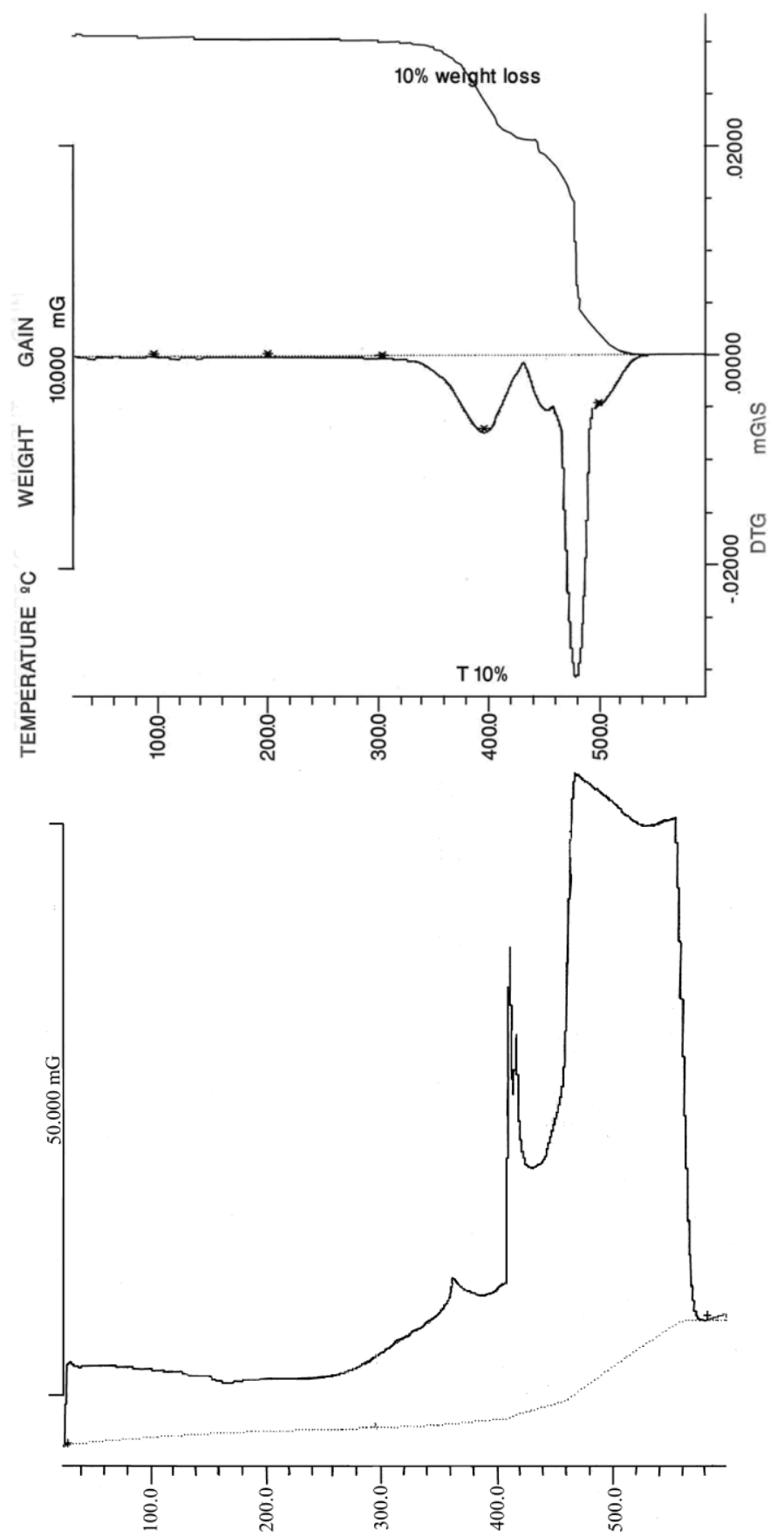

Fig. 7. TGA/DTG and DSC thermograms of Co-PEI ${ }_{6}$.

\section{Conclusions}

A series of optically active PEls and Co-PEls, having inherent viscosities of $0.31-$ $0.53 \mathrm{dl} \mathrm{g}^{-1}$ was synthesized for the first time by microwave-assisted polycondensation of optically active $N, N^{\prime}$-pyromelliticdiimido-di-L-leucine (3) as a diacid having a preformed imide rings as an "enlarged" monomer containing two chiral L-leucine groups with polyethyleneglycol-diol (PEG-200) and/or three synthetic bisphenols. 
These polymers showed optical activity $(+30.3$ to +51.5$)$ and also because of the presence of benzophenone moiety can potentially be photolabile. Co-PEls showed higher viscosities and better solubility than PEls. These polymers showed good thermal stability.

\section{Experimental part}

\section{Materials and Instruments}

Pyromellitic dianhydride (Merck) and 3,3',4,4'-benzophenonetetracarboxylic-3,3',4,4'dianhydride (Merck) were recrystallized from acetic anhydride. The other chemicals (Merck) were used as received. Micro SYNTH oven (Milestone) was used to perform reactions. ${ }^{1} \mathrm{H}$ NMR spectra were recorded on $300 \mathrm{MHz}$ instrument, using DMSO- $\mathrm{d}_{6}$ as solvent and tetramethylsilane as shift reference (tube diameter, $5 \mathrm{~mm}$ ). IR spectra were recorded on a Shimadzu IR-435 instrument, using $\mathrm{KBr}$ pellets. Mass spectra were recorded on a Fisons (UK) mass spectrometer Model Trio 1000. Specific rotations were measured by a JASCO P-1030 Polarimeter. Thermogravimetric analyses (TGA) were recorded on a Mettler TGA-50 with heating rate of $10{ }^{\circ} \mathrm{C} \mathrm{min}{ }^{-1}$ under air atmosphere. Differential scanning calorimetry (DSC) analyses were recorded on a Mettler DSC-30 under nitrogen atmosphere. Inherent viscosities of polymers were measured by a standard procedure using a KPG Cannon Fenske routine viscometer at $25^{\circ} \mathrm{C}$ using DMF as solvent. Melting points were measured in open capillaries with a Qallenkamp instrument.

\section{Monomer synthesis}

-Synthesis of N,N'-(pyromellitoyl)-bis-L-leucine diacid(3)

Into a $25 \mathrm{ml}$ round-bottomed flask, $2.523 \mathrm{~g}\left(7.83 \times 10^{-3} \mathrm{~mol}\right)$ of pyromellitic dianhydride (1), $2.056 \mathrm{~g}\left(1.57 \times 10^{-2} \mathrm{~mol}\right)$ of L-leucine (2), a mixture of acetic acid/ pyridine $(10 \mathrm{ml}$, $3: 2)$ and a stirring bar were placed. The mixture was stirred at r.t. for $2 \mathrm{~h}$ and then refluxed for $15 \mathrm{~h}$. The solvents were removed under reduced pressure. $5 \mathrm{ml}$ of cold concentrated $\mathrm{HCl}$ was added. A white precipitate was formed, filtered off, and washed with hot water. The solid was dried to leave $4.545 \mathrm{~g}(99.4 \%)$ of diacid 3 (Scheme 1).

mp: $292-294^{\circ} \mathrm{C} .[\alpha]_{D}^{25}=-4.08^{\circ}(0.050 \mathrm{~g}$ in $10 \mathrm{ml} \mathrm{DMF})$.

IR (KBr): 3650-3000, 2980, 2940, 2900, 1780, 1760, 1710, 1470, 1460, 1385, 1370, $1275,1240,1200,1160,1120,1090,1060,960,870,830,810,740,680,630,570$ $\mathrm{cm}^{-1}$.

${ }^{1} \mathrm{H}$ NMR (300MHz, DMSO- $\left.\mathrm{d}_{6}\right)$ ס: $0.94(\mathrm{~d}, 12 \mathrm{H}), 1.52(\mathrm{~m}, 2 \mathrm{H}), 1.92$ (ddd, $\left.2 \mathrm{H}\right), 2.25$ (ddd, 2H), 4.92 (dd, 2H), 8.35 (s, 2H), 13.27 (s, 2H) ppm.

Elemental analysis: Calculated for $\mathrm{C}_{22} \mathrm{H}_{24} \mathrm{~N}_{2} \mathrm{O}_{8}, \mathrm{C}(59.40 \%), \mathrm{H}(5.40 \%), \mathrm{N}(6.30 \%)$; found C (59.39\%), H (5.45\%), N (6.27\%).

-Synthesis of N,N'-(pyromellitoyl)-bis-L-leucine diacid chloride (4)

Into a $25 \mathrm{ml}$ round-bottomed flask were placed $1.00 \mathrm{~g}\left(2.240 \times 10^{-3} \mathrm{~mol}\right)$ of diacid (3), $10 \mathrm{ml}$ (an excess amount) of thionyl chloride and two drops of DMF. The mixture was refluxed for $2 \mathrm{~h}$. Unreacted thionyl chloride was removed under reduced pressure 
and the residue was washed with n-hexane, to leave $1.40 \mathrm{~g}(96.0 \%)$ of white crystals (Scheme 1).

dp: $128-130^{\circ} \mathrm{C} .[\alpha]_{D}^{25}=+1.20^{\circ}(0.050 \mathrm{~g}$ in $10 \mathrm{ml} \mathrm{DMF})$.

IR (KBr): 3550, 3100, 2950, 2910, 2900, 2850, 1850, 1775, 1720, 1465, 1460, 1440, $1380,1360,1270,1250,1230,1170,1150,1130,1120,1090,1040,990,950,940$, $920,870,840,820,760,740,720,660,620,600,560,500 \mathrm{~cm}^{-1}$.

Elemental analysis: Calculated for $\mathrm{C}_{22} \mathrm{H}_{22} \mathrm{~N}_{2} \mathrm{O}_{6} \mathrm{Cl}_{2}, \mathrm{C}(54.90 \%), \mathrm{H}(4.61 \%), \mathrm{N}$ (5.82\%); found C (55.12\%), H (4.67\%), N (5.97\%).

-Synthesis of N,N'-(pyromellitoyl)-bis-p-aminophenol (5)

Into a $25 \mathrm{ml}$ round-bottomed flask, $2.523 \mathrm{~g}\left(7.83 \times 10^{-3} \mathrm{~mol}\right)$ of pyromellitic dianhydride (1), $1.711 \mathrm{~g}\left(1.57 \times 10^{-2} \mathrm{~mol}\right)$ of $p$-amino phenol, $10 \mathrm{ml}$ of DMF and a stirring bar were placed. The mixture was stirred at r.t. for $2 \mathrm{~h}$ and then refluxed for $10 \mathrm{~h}$. The solvents were removed under reduced pressure. A bright yellow precipitate was formed, filtered off, and washed thoroughly with hot water. The solid was dried to leave 2.974 $\mathrm{g}(95 \%)$ of bisphenol (5) (Scheme 2).

$\mathrm{mp}>300^{\circ} \mathrm{C}$.

VIR (KBr): 3420, 1710, 1705, 1560, 1510, 1490-1410, 1405, 1260, 1140, 995, 815, $720 \mathrm{~cm}^{-1}$.

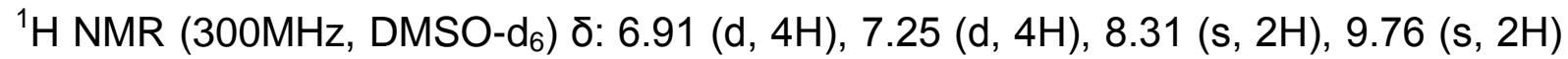
ppm.

Elemental analysis: Calculated for $\mathrm{C}_{22} \mathrm{H}_{12} \mathrm{~N}_{2} \mathrm{O}_{6}, \mathrm{C}(66.00 \%), \mathrm{H}(3.02 \%), \mathrm{N}(7.00 \%)$; found C (65.9\%), H (3.10\%), N (6.95\%).

-Synthesis of N,N'-(3,3',4,4'-benzophenonetetracarboxylic)-3,3',4,4'-diimido-bis-paminophenol (6)

Into a $25 \mathrm{ml}$ round-bottomed flask, $2.521 \mathrm{~g}\left(7.83 \times 10^{-3} \mathrm{~mol}\right)$ of $3,3^{\prime}, 4,4^{\prime}-$ benzophenonetetracarboxylic-3,3',4,4'-dianhydride, $1.711 \mathrm{~g}\left(1.57 \times 10^{-2} \mathrm{~mol}\right)$ of $p$ amino phenol, $10 \mathrm{ml}$ of DMF and a stirring bar were placed. The mixture was stirred at r.t. for $2 \mathrm{~h}$ and then refluxed for $10 \mathrm{~h}$. The solvents were removed under reduced pressure. A yellow precipitate was formed, filtered off, and washed thoroughly with hot water. The solid was dried to leave $3.70 \mathrm{~g}(94 \%)$ of bisphenol (6) (Scheme 2). $\mathrm{mp}>300^{\circ} \mathrm{C}$.

IR (KBr): 3450, 1780, 1708, 1660, 1600, 1518, 1450, 1390, 1250, 1207, 1120, 866, $824,715 \mathrm{~cm}^{-1}$.

${ }^{1} \mathrm{H}$ NMR $\left(300 M H z\right.$, DMSO-d $\left.\mathrm{d}_{6}\right) \delta: 6.89(\mathrm{~d}, 4 \mathrm{H}), 7.21(\mathrm{~d}, 4 \mathrm{H}), 8.15(\mathrm{br}, 4 \mathrm{H}), 8.25(\mathrm{~s}$, 2H), 9.71 (s, 2H) ppm.

Elemental analysis: Calculated for $\mathrm{C}_{29} \mathrm{H}_{16} \mathrm{~N}_{2} \mathrm{O}_{7}, \mathrm{C}(69.05 \%), \mathrm{H}(3.20 \%), \mathrm{N}(5.55 \%)$; found C (68.94\%), H (3.26\%), N (5.45\%).

-Synthesis of dihydroxy-[7a, 14c] dihydro-naphto[2,1-b] naphtha[1',2': 4, 5] furo[3,2-d] furan (7)

Into a $50 \mathrm{ml}$ round-bottomed flask, $3.20 \mathrm{~g}(0.02 \mathrm{~mol})$ of 2,7-naphthalene diol, $15 \mathrm{ml}$ $(0.01 \mathrm{~mol})$ of glyoxal $(30 \%)$ and $15 \mathrm{ml}$ of $\mathrm{AcOH}$ were placed. To the stirring mixture 4 
$\mathrm{ml}$ of $\mathrm{H}_{2} \mathrm{SO}_{4}$ (Conc.) was added dropwise. It was stirred for $24 \mathrm{~h}$ and then poured into water to precipitate. After recrystallization from $\mathrm{EtOH}$ and drying at $70{ }^{\circ} \mathrm{C}, 2.55 \mathrm{~g}$ (74\%) of white bisphenol (7) was left (Scheme 2).

$\mathrm{mp}=301^{\circ} \mathrm{C}$.

IR (KBr): $3500-3200,1640,1530,1460,1370,1210,1070,830 \mathrm{~cm}^{-1}$.

${ }^{1} \mathrm{H}$ NMR $\left(250 \mathrm{MHz}\right.$, DMSO-d $\left.\mathrm{d}_{6}\right) \delta: 9.82(\mathrm{~s}, 2 \mathrm{H}), 6.98-7.77(\mathrm{~m}, 8 \mathrm{H}), 5.58-5.60(\mathrm{~d}, 2 \mathrm{H})$, $3.55(\mathrm{~s}, 2 \mathrm{H}) \mathrm{ppm}$.

${ }^{13} \mathrm{C}$ NMR $\left(250 \mathrm{MHz}\right.$, DMSO-d $\left.\mathrm{d}_{6}\right) \delta$ : 156.6, 156.5, 132.3, 131, 130.6, 124.8, 117.6, $116.3,114.9,108.8,106.3,48.8 \mathrm{ppm}$.

\section{Polymerization}

\section{-Synthesis of polymers}

The PEls $(\mathbf{1}, \mathbf{2}$, and $\mathbf{3})$ were prepared by microwave-assisted polycondensation using the following general procedure:

General procedure for polymerization of $\mathrm{PEI}_{1}$ : Into a porcelain dish, a mixture of diacid chloride (4) $(0.481 \mathrm{~g}, 1.0 \mathrm{mmol})$ and DABCO $(0.222 \mathrm{~g}, 2.0 \mathrm{mmol})$ as a catalyst was placed. After grounding the reagents for $5 \mathrm{~min}$, bisphenol $5(0.400 \mathrm{~g}, 1.0 \mathrm{mmol})$ was added and the mixture was ground for further $5 \mathrm{~min} .0 .25 \mathrm{ml}$ of $O$-cresol as a solvent was added, and the mixture was ground for $5 \mathrm{~min}$. The reaction mixture was irradiated in a laboratory microwave oven (Micro SYNTH, Milestone) for $20 \mathrm{~min}$ (600W, Interval: $10 \mathrm{sec} / \mathrm{min}$ ). The resulting homogenous glassy compound film was isolated by adding methanol/ $\mathrm{H}_{2} \mathrm{O}(80: 20)$ and triturating, followed by filtration. It was washed several times with methanol and vacuum dried. White-gray; Yield $(\%)=90$; $\eta_{\text {inh }}\left(\mathrm{dl} \mathrm{g}{ }^{-1}\right)=0.37 ;[\alpha]_{D}^{25}=+30.3$

IR (KBr): 3380, 2995, 1730-1700, 1605, 1520, 1455, 1405-1360, 1250, 1205, 1175, $1140,1100,1050,910,850,810,715 \mathrm{~cm}^{-1}$.

${ }^{1} \mathrm{H}$ NMR $\left(300 \mathrm{MHz}\right.$, DMSO-d $\left.\mathrm{d}_{6}\right)$ : $\delta: 1.00(\mathrm{~d}, 12 \mathrm{H}), 1.63(\mathrm{br}, 2 \mathrm{H}), 2.12(\mathrm{br}, 2 \mathrm{H}), 2.30(\mathrm{br}$, 2H), 5.45 (br, 2H), 6.95 (d, 4H), $7.35(\mathrm{~d}, 4 \mathrm{H}), 8.35(\mathrm{~s}, 2 \mathrm{H}), 9.64(\mathrm{~s}, 2 \mathrm{H}) \mathrm{ppm}$.

Elemental analysis: calculated for $\mathrm{C}_{44} \mathrm{H}_{32} \mathrm{~N}_{4} \mathrm{O}_{12}, \mathrm{C}(65.34 \%), \mathrm{H}(3.99 \%), \mathrm{N}(6.93 \%)$; Found, C (65.12\%), H (4.11\%), N (6.78\%).

The other PEIs $(2,3)$ were prepared by the same procedure using the appropriate bisphenols (Scheme 3 ).

$\mathrm{PEI}_{2}$ : Gray; Yield $(\%)=85 ; \eta_{\text {inh }}\left(\mathrm{dl} \mathrm{g}^{-1}\right)=0.41$

$[\alpha]_{D}^{25}=+35.2 ;$

IR (KBr): 3385, 1780, 1730, 1710, 1650, 1565, 1510, 1431, 1376, 1244, 1205, 1150, $1105,823,725 \mathrm{~cm}^{-1}$.

Elemental analysis: calculated for $\left(\mathrm{C}_{51} \mathrm{H}_{36} \mathrm{~N}_{4} \mathrm{O}_{13}\right)_{n} \mathrm{C}(67.10 \%), \mathrm{H}(3.97 \%), \mathrm{N}(6.14 \%)$; Found $\mathrm{C}(66.67 \%), \mathrm{H}(4.05 \%), \mathrm{N}(6.03 \%)$.

$\mathrm{PEI}_{3}$ : White-gray; Yield $(\%)=87 ; \eta_{\text {inh }}\left(\mathrm{dl} \mathrm{g} \mathrm{g}^{-1}\right)=0.45$.

$[\alpha]_{D}^{25}=+38.1$; IR $(\mathrm{KBr}): 3380,1785-1705,1633,1565,1450,1385,1205,1160,1057$, $960,930,825,725 \mathrm{~cm}^{-1}$. 
Elemental analysis: calculated for $\left(\mathrm{C}_{44} \mathrm{H}_{34} \mathrm{~N}_{2} \mathrm{O}_{10}\right)_{n} \mathrm{C}(70.39 \%), \mathrm{H}(4.56 \%), \mathrm{N}(3.73 \%)$; Found $\mathrm{C}(69.98 \%), \mathrm{H}(4.68 \%), \mathrm{N}(3.68 \%)$.

\section{-Synthesis of copolymers}

The Co-PEls $(\mathbf{4}, \mathbf{5}$, and $\mathbf{6})$ were prepared by microwave-assisted polycondensation using the following general procedure:

General procedure for polymerization of Co-PEI 4 : Into a porcelain dish, a mixture of diacid chloride (4) $(0.481 \mathrm{~g}, 1.0 \mathrm{mmol})$ and DABCO $(0.222 \mathrm{~g}, 2.0 \mathrm{mmol})$ as a catalyst was placed. After grounding the reagents for $5 \mathrm{~min}$, polyethyleneglycol-diol (PEG200) $\left(0.100 \mathrm{~g}, 5 \times 10^{-4} \mathrm{~mol}\right)$ was added and the mixture was ground for further $5 \mathrm{~min}$. $0.25 \mathrm{ml}$ of $\mathrm{O}$-cresol as a solvent was added, and the mixture was ground for $5 \mathrm{~min}$. The reaction mixture was irradiated in a laboratory microwave oven (Micro SYNTH, Milestone) for $5 \mathrm{~min}(600 \mathrm{~W}$, Interval: $10 \mathrm{~s} / \mathrm{min})$. Diol $5\left(0.200 \mathrm{~g}, 5 \times 10^{-4} \mathrm{~mol}\right)$ and $0.25 \mathrm{ml}$ of $O$-cresol was added and the mixture was ground for further $5 \mathrm{~min}$. The reaction mixture was irradiated in a laboratory microwave oven (Micro SYNTH, Milestone) for $20 \mathrm{~min}(600 \mathrm{~W}$, Interval: $10 \mathrm{~s} / \mathrm{min}$ ). The resulting homogenous glassy compound film was isolated by adding methanol/ $\mathrm{H}_{2} \mathrm{O}(80: 20)$ and triturating, followed by filtration. It was washed several times with methanol and vacuum dried. Gray; Yield $(\%)=85 ;$ ńinh $_{\text {in }}\left(\mathrm{dl} \mathrm{g} \mathrm{g}^{-1}\right)=0.50 ;[\alpha]_{D}^{25}=+51.5$.

IR (KBr): 3380, 1780-1750, 1715, 1650, 1600, 1580, 1510, 1455, 1380, 1240-1210, $1155,1110,1095,870,845,805,735 \mathrm{~cm}^{-1}$.

Elemental analysis: calculated for $\mathrm{C}_{74} \mathrm{H}_{70} \mathrm{~N}_{6} \mathrm{O}_{23}, \mathrm{C}(62.97 \%), \mathrm{H}(4.99 \%), \mathrm{N}(5.95 \%)$; Found, C (62.94\%), H (4.97\%), N (5.89\%).

The other Co-PEIs $(\mathbf{5}, \mathbf{6})$ were prepared by the same procedure using the appropriate bisphenols (Scheme 4).

Co-PEI 5 : Gray; Yield $(\%)=78 ;$ ńinh $_{\text {in }}\left(\mathrm{dl} \mathrm{g}{ }^{-1}\right)=0.49 .[\alpha]_{D}^{25}=+38.2$.

IR (KBr): 3380, 1780-1745, 1715, 1655, 1595, 1575, 1505, 1450, 1380, 1235-1205, $1150,1105,1075,880,845,805,740 \mathrm{~cm}^{-1}$.

Elemental analysis: calculated for $\left(\mathrm{C}_{81} \mathrm{H}_{74} \mathrm{~N}_{6} \mathrm{O}_{24}\right)_{n} \mathrm{C}(64.19 \%), \mathrm{H}(4.92 \%), \mathrm{N}(5.54 \%)$; Found $\mathrm{C}(63.86 \%), \mathrm{H}(4.95 \%), \mathrm{N}(5.48 \%)$.

Co-PEI 6 : Pale green; Yield $(\%)=80$;

IR (KBr): 3350, 2995, 1780, 1725, 1630, 1580, 1510, 1455, 1380, 1350, 1280-1030, $955,915,850,830,715 \mathrm{~cm}^{-1}$.

Elemental analysis: calculated for $\left(\mathrm{C}_{74} \mathrm{H}_{72} \mathrm{~N}_{4} \mathrm{O}_{21}\right)_{n} \mathrm{C}(65.67 \%), \mathrm{H}(5.36 \%), \mathrm{N}(4.14 \%)$; Found $\mathrm{C}(65.61 \%), \mathrm{H}(5.34 \%), \mathrm{N}(4.15 \%)$.

\section{Acknowledgements}

We gratefully acknowledge the funding support received for this project from the Estahban Payamenoor University (pnu), IR Iran and Grant GM 33138 (AER) from the National Institutes of Health, USA.

\section{References}

[1] Mittal, K.L. Polyimides: Synthesis, Characterization and Application. New York: Plenum, 1984. 
[2] Abade, M.J.M. Ed. Polyimides and other High-Temperature Polymers. New York: Elsevier, 1991.

[3] Banihashemi, A.; Abdolmaleki, A. European Polymer Journal, 2004, 40, 1629.

[4] Ghosh, M.K.; Mittal, K.L. Ed. Polyimide: Fundamentals and applications. New York: Marcel Dekker, 1996.

[5] Wilson, D.; Stenzenberger; Hergenrother, Polyimides. Blackie: Glasgow, 1990.

[6] Tamai, S.; Yamaguchi, A.; Ohta, M. Polymer, 1996, 37, 3683.

[7] Hsiao, S.H.; Li, C.T. Macromolecules, 1998, 31(21), 7213.

[8] Li, F.; Ge, J.J.; Honigfort, P.S.; Fang, S.; Chen, J.C.; Harris, F.W.; and et al. Polymer, 1999, 40, 4987.

[9] Reddy, D.S.; Chou, C.H.; Hsu, C.F.; Lee, G.H. Polymer, 2003, 44, 557.

[10] Legge, N.R.; Holden, G.; Schroeder, H.E. Thermoplastic Elastomers. Hanser: New York, 1987.

[11] Noshay, A.; McGrath, I.E. Block Copolymers. Academic Press: New York, 1977. [12] (a) Mallakpour, S.E.; Hajipour, A.R.; Khoee, S. J. Polym. Sci. Polym. Chem. Ed., 2000, 38, 1154. (b) Hu, Q.S.; Sun, C.; Monaghan, C.E.; Tet. Lett., 2001, 42, 7725.

[13] Akekah, A.; Sherrington, D.C. Chem. Rev., 1981, 81, 557.

[14] Alietto, M.; Chiellini, E.; Antone, S.D.; Ruggeri, G.; Solaro, R. Pure Appl. Chem., 1988, 60, 415.

[15] Yuki, H.; Okamoto, Y.; Okamoto, I. J. Am. Chem. Soc., 1980, 102, 6358.

[16] Okamoto, Y.; Yashima, E. Angew. Chem. Int. Ed. Engl., 1999, 37, 1020.

[17] Soai, K.; Nina, S. Chem. Rev. 1992, 92, 833.

[18] Wulff, G. Angew. Chem. Int. Engl. Ed., 1989, 28, 21.

[19] Ciardelli, F. Ecycl. Polym. Sci. Engng., 1987, 10, 463.

[20] Farina, M. Topics Stereochem., 1987, 17, 1.

[21] Fontanille, M.; Guyot, M. editor, Recent advances in synthetic and mechanistic aspects of polymerization. Dordrecht, Netherlands, 1987.

[22] (a) Birchall, A.C.; Bush, S.M.; North, M. Polym. J., 2001, 42, 375. (b) Langer, R. ACC.; Chem. Res., 2000, 33, 94. (c) Sanda, F.; Endo, T. Macromol. Chem. Phys., 1999, 2000.

[23] Mallakpour, S.E.; Hajipour, A.R.; Vahabi, R.J. J. Appl. Polym. Sci., 2002, 84, 35. [24] Mallakpour, S.E.; Hajipour, A.R.; Khoee, S.; Sheikholeslami, B. Polym. Int.,1998, 47, 193.

[25] Mallakpour, S.E.; Hajipour, A.R.; Mahdavian, A.R.; Rafiemanzelat, F. Polym. Int., 1999, 48, 109.

[26] Hajipour, A.R.; Zahmatkesh, S.; Zarei, A.; Khazdooz, L.; Ruoho, A.E. Eur. Polym. J., 2005, 41, 2290.

[27] Gedye, R.; Smith, F.; Westaway H.A.; Baldisera, L.; Laberge L.; Rousell J. Tet Lett., 1986, 27, 279.

[28] Abramovich, R.A. Org Prep Proceed Int., 1991, 23, 683.

[29] Limousin, C.; Cleophax, J.; Loupy, A.; Petti, A. Tetrahedron, 1998, 54,13567.

[30] Loupy, A.; Regnier, S. Tet Lett., 1999, 40, 6221.

[31] Chatti, S.; Bortolussi, M.; Loupy, A.; Blais, J.C.; Bogdal, D.; Majdoub, M. Eur Polym J, 2002, 38, 1851.

[32] Hajipour, A.R.; Mallakpour, S.E.; Khoee, S. Synlett, 2000, 5, 740.

[33] Mallakpour, S.E.; Hajipour, A.R.; Khoee, S. J Polym Sci Polym Chem Ed, 2000, 38, 1154.

[34] Mallakpour, S.E.; Hajipour, A.R.; Faghihi, K. Polym Int, 2000, 49,1383.

[35] Mallakpour, S.E.; Hajipour, A.R.; Faghihi, Kh. Eur. Polym. J., 2001, 37, 119. 
[36] Jones, J.; In: Katritzky, A.R. Comprehensive Heterocyclic Chemistry, Vol. 2, part 2A, Oxford, Pergamon press, 1984, P 395.

[37] Guo, L.W.; Hajipour, A.R.; Gavala, M.L.; Grant, J.E.; Ruoho, A.E. FASEB Journal, 2004, 18, A587. 